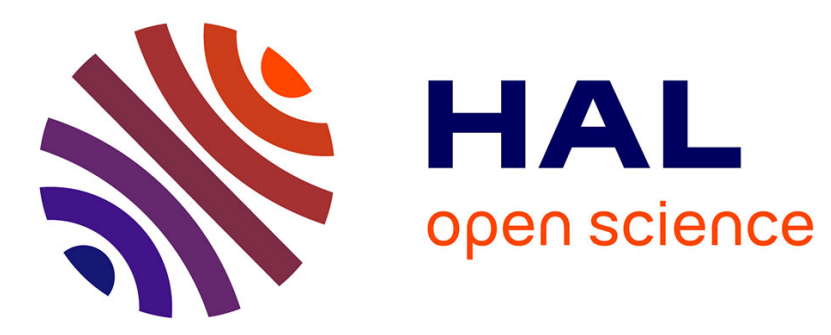

\title{
Valence, coordination number, and PAV cells in metallic rare earth compounds \\ F. Carter
}

\section{To cite this version:}

F. Carter. Valence, coordination number, and PAV cells in metallic rare earth compounds. Journal de Physique Colloques, 1979, 40 (C5), pp.C5-216-C5-217. 10.1051/jphyscol:1979581 . jpa-00218998

\section{HAL Id: jpa-00218998 https://hal.science/jpa-00218998}

Submitted on 1 Jan 1979

HAL is a multi-disciplinary open access archive for the deposit and dissemination of scientific research documents, whether they are published or not. The documents may come from teaching and research institutions in France or abroad, or from public or private research centers.
L'archive ouverte pluridisciplinaire HAL, est destinée au dépôt et à la diffusion de documents scientifiques de niveau recherche, publiés ou non, émanant des établissements d'enseignement et de recherche français ou étrangers, des laboratoires publics ou privés. 


\title{
Valence, coordination number, and PAV cells in metallic rare earth compounds
}

\author{
F. L. Carter \\ Naval Research Laboratory, Washington, D.C. 20375, USA
}

\begin{abstract}
Résumé. - On présente les volumes atomiques polyédriques, les volumes de Voronoi, les nombres de coordination généralisés, et les valences métalliques de Pauling pour 24 composés intermétalliques des terres rares. Les résultats montrent clairement qu'une contraction de volume, à valence constante des terres rares atteignant $33 \%$ peut se produire lors de la formation du composé, tandis que les volumes atomiques d'aluminium et des éléments de transition sont presque constants.
\end{abstract}

\begin{abstract}
Polyhedral atomic volumes, Voronoi volumes, generalized coordination numbers, and Pauling's metallic valences are given for 24 intermetallic rare earth compounds. The results clearly indicate that as much as $33 \%$ rare earth isovalent volume contraction can occur upon compound formation while the atomic volumes of aluminum and the transition elements are nearly constant.
\end{abstract}

Earlier discussions of bond formation in rare earth compounds [1-5] using Pauling's metallic radii [6] and the bidirectional orbital approximation [7] have strongly suggested that the effective radius of the rare earth atoms is surprisingly variable and may even be anisotropic in some $\mathrm{SmCo}_{5}$-type [4] and Laves phase [5] compounds. The power of these methods, i.e. Pauling's metallic radii (PMR) and the bidirectional orbital approximation (BOA), combined with the concept of the Voronoi cell [8], is indicated not only by the prediction [4] of the unstability of the $\mathrm{SmCo}_{5}$ structure [9], but even to the likely nature of one of the $\mathrm{SmCo}_{5}$-type distortions. For the first time this paper demonstrated conclusively for a variety of rare earth intermetallic compounds that the wide variations of volume contractions in intermetallic compound formation is due almost wholly to the rare earth atoms. This is possible because the approach permits the calculation of individual atomic volumes, i.e. the calculation of Polyhedral Atomic Volumes (PAVs), through the self-consistent application of PMR to the structural data.

A Voronoi cell [8] is constructed for an atom with planes perpendicularly bisecting the interatomic distances. For atoms of unequal size PAV cells are similarly formed with the planes bisecting the distance between the surfaces of the atoms (even if overlapping). Here the radii of the atoms are taken to be the single bonded radii $R 1$ of Pauling $[6,7]$ which are a function of hybridization, valence and charge. In Pauling's semiempirical approach the valence $V_{i}$ of the ith atom is the sum of the bond orders $n_{i j}$ obtained from the interatomic distances $d_{i j}$ via the formula : $0.60 \log n_{i j}=R 1(i)+R 1(j)-d_{i j}$. The valence, $V_{i}=\sum_{i} n_{i j}$, is then the number of bonding electrons employed by the atom. In order to apply
PMR self-consistently it was necessary to increase the rare earth metal $d$-character and hence decrease the rare earth radius $R 1$ as observed previously $[4,5]$. It was not found necessary or useful to vary the transition metal $d$-character.

From table I it is seen that the PAVs for $\mathrm{Al}$ and the transition metals are quite constant, with small ranges, for a variety of valences and coordination numbers $C N_{v}$. These non-integer $C N$ are based on a mathematical generalization of the concept of $C N$ using in this case the volumes $(V)$ of the various pyramids comprising the PAV cells [10].

Table I. - Aluminum and transition metals.

$\begin{array}{cccccc} & R 1 & \text { Valence } & \text { PAV } & \text { PAV } & \\ - & - & - & - & - & C N_{v} \\ \mathrm{~A} 1 & 1.248 & 2.5-3.3 & 17.2-18.3 & 17.38 & 9.8-11.9 \\ \mathrm{Co} & 1.162 & 3.1-5.5 & 11.5-12.8 & 12.29 & 8.2-12.2 \\ \mathrm{Ni} & 1.155 & 3.4-4.6 & 12.1-13.6 & 13.06 & 8.7-12.0 \\ \mathrm{Pd} & 1.280 & 3.4-5.8 & 16.0-18.1 & 17.04 & 8.5-8.8 \\ \mathrm{Pt} & 1.294 & 3.5-5.0 & 17.0-19.0 & 18.06 & 9.6-11.9\end{array}$

However for the rare earths of table II we note that the PAV ranges can be very large, indicating that the rare earth is undergoing the maior part of the contraction and not the transition metal during compound formation. Thus $\mathrm{Sm}$ in $\mathrm{Sm}_{5} \mathrm{Co}_{2}$ and $\mathrm{SmCo}_{2}$ has a $29.2 \%$ volume difference, $\mathrm{Gd}$ in $\mathrm{Gd}_{3} \mathrm{Co}$ and $\mathrm{Gd}_{2} \mathrm{Co}_{7}$, a $33 \%$ difference, and $\mathrm{Ho}$ in $\mathrm{Ho}_{2} \mathrm{Al}$ and $\mathrm{Ho}_{12} \mathrm{Co}_{7}$, a $26.9 \%$ difference. To indicate that this is not an artifact of the PMR calculations we note that this difference is also strongly reflected in the Voronoi volumes as well where the atoms have zero size. We also note that this is not an effect of 
Table II. - Rare earth and yttrium.

$\begin{array}{lcccc} & R 1 & \text { Valence } & \text { PAV } & C N_{v} \\ \mathrm{Ce}(*) & 1.45 & 3.4-4.4 & 22.2-24.0 & 15.7-19.0 \\ \mathrm{Sm} & 1.49-1.58 & 3.1-3.3 & 22.7-32.2 & 13.2-19.5 \\ \mathrm{Eu} & 1.61 & 1.6-3.0 & 31.0-36.6 & 14.0-14.5 \\ \mathrm{Gd} & 1.43-1.61 & 2.6-3.6 & 21.1-32.7 & 13.2-19.2 \\ \mathrm{~Tb} & 1.49-1.50 & 3.1-3.6 & 26.8-27.1 & 14.7-15.2 \\ \mathrm{Dy} & 1.49 & 4.3 & 24.1 & 12.47 \\ \mathrm{Ho} & 1.45-1.56 & 3.2-4.4 & 21.5-29.4 & 12.3-19.0 \\ \mathrm{Er} & 1.38-1.43 & 3.3 & 20.9-23.8 & 19.1 \\ \mathrm{Yb} & 1.36-1.45 & 2.5-3.6 & 20.7-25.2 & 11.9-16.7 \\ \mathrm{Lu} & 1.44 & 3.5 & 24.3 & 14.5 \\ \mathrm{Y} & 1.46-1.47 & 3.2-3.3 & 24.7-25.3 & 12.4-12.9\end{array}$

(*) Compounds : $\mathrm{Ce}_{2} \mathrm{Ni}_{17}, \mathrm{Sm}_{5} \mathrm{Co}_{2}, \mathrm{SmCo}_{2}, \mathrm{SmCo}_{5}, \mathrm{Eu}_{3} \mathrm{Pd}_{2}$, $\mathrm{Gd}_{3} \mathrm{Al}_{2}, \mathrm{GdAl}_{3}, \mathrm{Gd}_{3} \mathrm{Co}, \mathrm{Gd}_{2} \mathrm{Co}_{7}, \mathrm{GdNi}, \mathrm{Gd}_{7} \mathrm{Pd}_{2}, \mathrm{TbNi}(\mathrm{LT})$, $\mathrm{TbNi}(\mathrm{HT}), \mathrm{DyAl}_{3}, \mathrm{Ho}_{2} \mathrm{Al}, \mathrm{Ho}_{12} \mathrm{Co}_{7}, \mathrm{HoAl}_{3}, \mathrm{HoCo}_{3}, \mathrm{Er}_{2} \mathrm{Co}_{17}$, $\mathrm{YbMoAl}_{4}, \mathrm{YbPt}, \mathrm{Yb}_{3} \mathrm{Pt}_{4}, \mathrm{LuNi}, \mathrm{YAl}_{3}$.

electronegativity difference as a $21 \%$ contraction in Ho PAV volume exists between $\mathrm{Ho}_{2} \mathrm{Al}$ and $\mathrm{HoAl}_{3}$. Figure 1 illustrates a similar contraction for cobalt compounds as a function of composition (or partial coordination number $[9,10]$ ) as well as the constancy of the cobalt volume.

For the cobalt rich compounds $\mathrm{SmCo}_{2}, \mathrm{SmCo}_{5}$, $\mathrm{Gd}_{2} \mathrm{Co}_{7}$ and $\mathrm{HoCo}_{3}$ is was necessary to assume an anisotropic rare earth radius in order to achieve PMR self-consistency. Thus the $\mathrm{Sm}-\mathrm{Sm}$ bonds in
PAV VS COMPOSITION

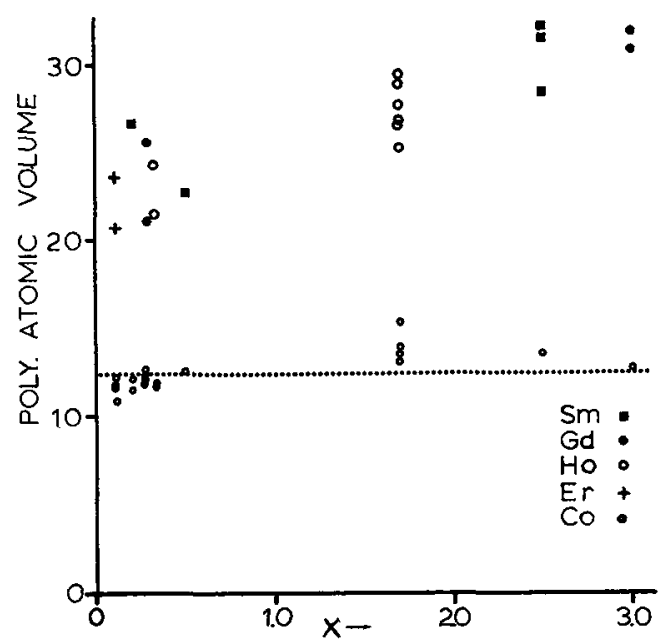

Fig. 1. - Rare earth and cobalt PAV's are plotted as a function of the parameter $x$ for the compounds of composition $\mathrm{RCo}_{x}$. The dotted line is the average cobalt PAV.

$\mathrm{SmCo}_{2}$ and the basal plane Sm-Co bonds in $\mathrm{SmCo}_{5}$ were associated with a much shorter $\mathrm{Sm}$ radius as if much higher $d$-character (or possible $f$-character) was involved in the bonding. From a chemical bonding picture (BOA) these have been rationalized [3-5] as a result of hybridization and anisotropic shielding.

\section{References}

[1] Laves, F., Theory of Alloy Phases (ASM, Cleveland, Ohio) 1956 , p. 124.

[2] Pauling, L., ibid. 220.

[3] Carter, F. L., Proc. 7th Rare Earth Res. Conf., Coronado, Calif. (Oct. 1968) 283.

[4] Carter, F. L., Proc. 9th Rare Earth Res. Conf., ed. D. E. Field, Blackburg, Va., Vol. 2 (Oct. 1971) 617.

[5] Carter, F. L., Proc. 10th Rare Earth Res. Conf., Carefree, Ariz. (April 1973) 1044.
[6] Pauling, L., Nature of the Chemical Bond, 3rd ed. (Cornell Univ. Press, Ithaca, New York) 1960.

[7] Carter, F. L., Electronic Densities of State, ed. L. H. Bennett, Nat. Bur. Standards, Spec. Pub. \# 323 (1971) 385.

[8] VoronoI, G., J, reine und angew. Math. 134 (1908) 198.

[9] Brozder, F. J. A. and Buschow, K. H. J., J. Less-Common Metals 29 (1972) 65.

[10] Carter, F. L., Acta Cryst. B 34 (1978) 2962.

[11] CarTer, F. L., J. Less-Common Metals 47 (1976) 157. 